\title{
Mooney Viscosity Determination Of Rubber With A Charm Filler
}

\author{
Rudi Munzirwan Siregar \\ Department of Chemistry, Faculty of Mathematics and Sciences, Medan State University, Medan 20221, \\ Indonesia \\ *Email : rudimunzirwan@yahoo.com
}

\begin{abstract}
Research on the Determination of Viscosity Mooney From Rubber by Fillers Charcoal has been done. Each latex was added into the coconut shell charcoal (particle size 80 mesh) were 36, 38, 40, 42, and 44 gram. Then the latex is coagulated with formic acid in $p H 4$ 4.7. Formic acid is used as a control for the rubber crumple without the addition of coconut shell. Research carried out by measuring the quality of rubber Money Viscosity. From the results of research it turns out that the value of the viscosity of the money obtained by the addition of charcoal to the rubber in the latex is $72.5 ; 74 ; 75.5 ; 77$; and 75 . It can be seen that the value of the best rubber Mooney viscosity of 75 , so the rubber with medium Mooney viscosity value able to provide a meeting point between the energy efficient with superior physical properties .
\end{abstract}

Keywords: Rubber, Mooney Viscosity , Coconut Shell Charcoal

\section{Pendahuluan}

Salah satu kelemahan pokok karet alam dibandingkan dengan karet sintesis adalah nilai viskositas Mooneynya yang sangat bervariasi sehingga menyulitkan konsumen dalam membuat kompon barang jadi karet, khususnya ban. ${ }^{1}$ Sehingga perkembangan akhir-akhir ini menunjukkan bahwa setiap konsumen (pabrik ban) menghendaki nilai viskositas Mooney karet pada jarak tertentu, misalnya Goodyear antara 65-75, Michelin 80-85, Yokohama 75-85, dan Alliance $62-72.2$

Hal ini menunjukkan bahwa setiap konsumen menginginkan konsistensi nilai viskositas Mooney dari produsen karet, atau dengan kata lain setiap konsumen menghendaki kemantapan nilai viskositas Mooney dari produsen karet. ${ }^{3}$ Pengujian viskositas Mooney dilakukan dengan proses shearing (gesekan) yang mirip dengan proses pencampuran karet dan bahan-bahan lain dalam pembuatan kompon karet dibandingkan dengan pengujian Po (plastisitas) yang hanya berdasarkan tekanan terhadap sampel karet dan hasilnya. ${ }^{4}$ Juga dalam pembuatan kompon dikehendaki nilai viskositas Mooney tertentu supaya pencampuran antara dua jenis karet atau lebih yang berbeda dapat dilakukan dengan mudah dan tidak memerlukan energi yang banyak.

Dilain pihak arang dapat digunakan sebagai bahan pengisi karet yang aktif yaitu bahan pengisi yang fungsinya selain memperbesar volume juga dapat memperbaiki kekerasan karetnya ${ }^{1}$

\section{Metode Penelitian}

\subsection{Alat dan Bahan.}

Alat yang digunakan dalam penelitian ini adalah Blanding mill, Lab mill, Wallace punch, Wallace plastimeter, Creper, Neraca analitis, Termometer, Stopwatch, Oven, dan Desikator. Bahan yang digunakan adalah Lateks, Asam formiat, Arang yang diayak dengan ukuran 80 mesh, dan kertas lakmus indikator. 


\subsection{Prosedur Kerja}

\section{Pembuatan Arang Dari Tempurung Kelapa. 5}

Sebanyak 2 buah tempurung kelapa dibersihkan, dijemur di bawah sinar matahari, dan dipotong menjadi ukuran yang lebih kecil lalu dimasukkan ke dalam cawan porselin dan ditutup dengan aluminium foil. Selanjutnya dimasukkan ke dalam tanur pada suhu $500{ }^{\circ} \mathrm{C}$ selama 4 jam, lalu didinginkan dalam desikator dan dicuci dengan akuades. Arang yang terbentuk diovenkan pada suhu $100-105^{\circ} \mathrm{C}$, lalu didinginkan dalam desikator dan diayak dengan ayakan 80 mesh.

\section{Asam Formiat sebagai Penggumpal Lateks dengan bahan pengisi arang}

Disediakan lateks sebanyak 4 liter. Lateks kebun disaring dengan saringan 40 mesh untuk menghilangkan kotoran-kotoran yang terikut pada waktu penyadapan. Masing-masing 1 liter lateks dimasukkan kedalam 4 mangkuk penggumpal, untuk mangkuk 1; 1 liter lateks ditambahkan arang yang ukuran partikelnya 80 mesh sebanyak 42 gram, lalu ditambahkan sedikit demi sedikit asam

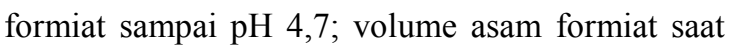
pH 4,7 adalah $20 \mathrm{ml}$. Untuk mangkuk ke 2 sampai ke 3 dilakukan hal yang sama seperti mangkuk 1. Sedangkan untuk mangkuk 4; 1 liter lateks langsung ditambahkan sedikit demi sedikit asam formiat sampai $\mathrm{pH}$ 4,7 tanpa penambahan arang. Masing-masing koagulum karet yang terbentuk ditambahkan air secukupnya untuk menutupi permukaan koagulum tersebut, kemudian didiamkan selama satu malam. Selanjutnya masing-masing koagulum digiling dengan alat creper sebanyak sembilan kali gilingan dan diovenkan pada suhu $110{ }^{\circ} \mathrm{C}$.

\section{Pengujian Viskositas Mooney}

Sebelum pengukuran dilakukan, alat viskosimeter terlebih dahulu dipanaskan selama satu jam. Masing-masing lembaran contoh karet diambil 2 buah potongan uji dengan menggunakan alat Wallace punch sehingga ukuran diameternya sama dengan ukuran diameter rotor. Ditusukkan rotor ke contoh karet pertama yang telah diberi lubang dengan gunting. Contoh kedua diletakkan tepat di atas rotor lalu dimasukkan bersama-sama ke stator bawah. Ditutup stator atas dan setelah tertutup stopwatch dihidupkan. Setelah tepat satu menit, dijalankan rotor. Nilai viskositas dibaca dengan alat penunjuk. Angka yang ditunjukkan jarum mikrometer setelah menit keempat adalah nilai viskositas karet .

\section{Hasil dan Pembahasan}

\subsection{Viskositas Mooney}

Viskositas karet mentah dinyatakan sebagai viskositas mooney, yang menunjukkan panjangnya rantai molekul, berat molekul, dan derajat pengikatan silang rantai molekulnya. Jika nilai viskositas tinggi berarti karet keras sehingga mutu karet yang dihasilkan tinggi sebaliknya jika nilai viskositas rendah berarti karet lunak sehingga mutu karet yang dihasilkan turun. ${ }^{6,7}$ Hasil Viskositas Mooney dengan penggumpal asam formiat dapat dilihat pada Tabel1.

Tabel 1. Viskositas Mooney karet dengan penggumpal Asam Formiat

\begin{tabular}{|c|c|c|c|c|}
\hline \multirow[t]{2}{*}{ Perlakuan } & \multicolumn{3}{|c|}{$\begin{array}{c}\text { Nilai } \\
\text { Viskositas } \\
\text { Mooney }(\%)\end{array}$} & \multirow{2}{*}{$\begin{array}{c}\text { Jenis } \\
\text { SIR }\end{array}$} \\
\hline & 1 & 2 & $\begin{array}{l}\text { Rata- } \\
\text { rata }\end{array}$ & \\
\hline Kontrol & 66 & 64 & 65 & SIR 5 \\
\hline $36 \mathrm{~g}$ arang & 72 & 73 & 72,5 & SIR 5 \\
\hline $38 \mathrm{~g}$ arang & 75 & 73 & 74 & SIR 5 \\
\hline $40 \mathrm{~g}$ arang & 76 & 75 & 75,5 & SIR 5 \\
\hline 42 g arang & 76 & 78 & 77 & SIR 5 \\
\hline 44 gr arang & 75 & 75 & 75 & SIR 5 \\
\hline
\end{tabular}

Tabel 1 menunjukkan bahwa penambahan arang kedalam lateks dengan penggumpal asam formiat menghasilkan nilai viskositas mooney yang lebih tinggi bila dibandingkan dengan kontrol (tanpa penambahan arang), karena dengan penambahan penggumpal lateks dan arang, maka kandungan senyawa bukan karet yang berfungsi sebagai katalis pembentuk ikatan silang terlarut dalam fase serum, sehingga karet yang dihasilkan keras dan mempunyai ketahanan yang tinggi terhadap gesekan.$^{8,9}$

Dari Tabel 1 diatas juga diketahui bahwa nilai rata-rata viskositas mooney karet tertinggi terdapat pada penambahan arang 44 gram. Hal ini berarti dengan penambahan arang 44 gram ke dalam lateks menghasilkan karet yang nilai viskositas mooney 
karetnya berada di medium (sedang). Sehingga karet dengan nilai viskositas Mooney medium (sedang) dapat memberikan titik temu antara energi yang hemat dengan sifat fisika yang unggul. ${ }^{10}$

\section{Kesimpulan}

Dari hasil penelitian yang telah dilakukan dapat disimpulkan bahwa nilai viskositas Mooney karet tertinggi terdapat pada penambahan arang 44 gram. Hal ini berarti dengan penambahan arang 44 gram kedalam lateks menghasilkan karet yang nilai viskositas money karetnya berada di medium(sedang). Sehingga karet dengan nilai viskositas money medium (sedang) dapat memberikan titik temu antara energi yang hemat degan sifat fisik yang unggul

\section{Referensi}

1. Budiman, S. (1983). Rencana Perbaikan Pengolahan Karet Rakyat Dalam Perbaikan Mutu Ekspor, Kelompok teknologi pengolahan hasil pusat penelitian perkebunan sungai putih, 1: $20-25$

2. Ompusunggu, M. (1995). Pengetahuan Umum Lateks, Balai Penelitian Perkebunan Sei Putih

3. Honggokusumo, S. (1994). Permintaan Konsumen Mengenai Spesifikasi SIR, Warta Perkaretan, $3:$ 30-35

4. Soewarti, (1995). Pengaruh Arang dan $\mathrm{pH}$ terhadap Lateks Kebun dengan sifat Karet yang diperoleh, Menara Perkebunan, 43: 20-25

5. Anna, H. M (2003). Pemanfaatan Arang Cangkang emiri dan Arang Aktif Cangkang Kemiri Untuk Menyerap Logam Krom dengan spektrofotometri Serapan Atom”. Skripsi, Jurusan Kimia, FMIPA USU.

6. Subramaniam, A. (1984). Mooney Viscocity of Raw Natural Rubber, Rubber Research Institute Malaysia, 2: 30-40

7. Lim HS. (1989). Processing of Viscosity Stabilised Natural Rubber, Divisi American Chemistry Society, Detroid Michigan.

8. Haradi, B. (1982). Usaha Perbaikan Mutu Bahan Olah Karet. Direktorat Jendral Perkebunan.

9. Kartowardoyo, S. (1980). Penggunaan Wallace Plastimeter untuk penentuan karakteristikkarakteristik

10. Nelteresia. (1999). Pemanfaatan Destilat Limbah Cair Kakao Sebagai Penggumpal Lateks, Skripsi, Jurusan Kimia FMIPA USU. 